\title{
KETAHANAN NASIONAL BERBASIS KOKOHNYA KELUARGA INDONESIA MEMASUKI MASYARAKAT EKONOMI ASEAN (MEA)
}

\author{
Dr. Yudiyanto, M.Si. \\ Dosen STAIN Jurai Siwo Metro \\ yudiyudi0222@gmail.com
}

\begin{abstract}
Without knowing us, the Indonesian nation security has potential to debilitate when take part in ASEAN Economic Society (MEA). ASEAN expand market will make charity in flow of goods, services, and labors followed by cultural influence. Not only has the positive impact, ASEAN expanded market also give negative impact because of hedonist and materialist culture influence. Family is the first institution creating individuals as the candidate of society and nation. The strong family is capable both in creating and educating the next generation who has balancing in spiritual, intellectual, and emotional which can help them in MEA competition arena. Those excellent generations have important role in community and national endurance in the middle of regional rivalries ASEAN nations in MEA. The aim of this paper is to explain the important role of family in creating national endurance when take part in MEA, through qualitative conceptual paper method and using literature review.
\end{abstract}

Key words: Family, National Security, MEA

\begin{abstract}
Abstrak
Memasuki komunitas Masyarakat Ekonomi ASEAN (MEA) potensi melemahnya ketahanan nasional Indonesia dapat terjadi tanpa kita sadari. Pasar bebas ASEAN akan menumbuhkan berbagai kemudahan aliran arus barang, jasa dan tenaga kerja yang diikuti pengaruh budaya. Selain pengaruh positif tersebut, pasar bebas ASEAN juga akan memberikan dampak negatif adanya pengaruh budaya hedonis dan materialistik. Pengaruh budaya negatif tersebut akan mempengaruhi ketahanan nasional bangsa Indonesia. Keluarga merupakan institusi pertama tempat mencetak pribadi-pribadi calon pengisi dan penyusun masyarakat dan bangsa. Kokohnya keluarga akan mampu mencetak dan mendidik anak sehingga melahirkan generasi unggul seimbang antara spiritual, intelektual dan emosional yang siap berkompetisi dalam arena MEA. Lahirnya generasi unggul tersebut juga akan menopang ketahanan masyarakat dan ketahanan nasional ditengah persaingan regional bangsa-bangsa ASEAN dalam MEA. Tulisan ini bermaksud menjelaskan peranan penting keluarga dalam mewujudkan ketahanan nasional dalam memasuki MEA, melalui metode conceptual paper, dengan kajian yang bersifat kualitatif melalui studi pustaka terakit.
\end{abstract}

Kata kunci: Keluarga, Ketahanan Nasional, MEA

\section{Pendahuluan}

Pada tahun 2015 ini, Indonesia dan beberapa Negara ASEAN memasuki babak baru pergaulan regional antar bangsa-bangsa ASEAN dengan mulai berlakunya pasar bebas ASEAN dalam format ASEAN Economic Community (AEC) atau Masyarakat Ekonomi ASEAN (MEA). MEA merupakan realisasi pasar bebas di Asia Tenggara yang telah dirumuskan dalam Framework Agreement on Enhancing ASEAN Economic Cooperation pada tahun 1992.

Adanya MEA menumbuhkan terciptanya pasar bebas di bidang permodalan, barang dan jasa, serta tenaga kerja. Beberapa dampak konsekuensi 
atas kesepakatan MEA antara lain adanya aliran bebas barang bagi negaranegara ASEAN, dampak arus bebas jasa, arus bebas investasi, arus tenaga kerja terampil, dan dampak arus bebas modal. Memasuki MEA saat ini, pemerintah Indonesia diharapkan telah dan terus dapat mempersiapkan langkah strategis, khususnya di bidang pendidikan, karena pendidikan merupakan pencetak sumber daya manusia (SDM) berkualitas yang menjadi jawaban terhadap kebutuhan sumber daya manusia dalam bersaing di MEA.

Kompetisi diantara Negara anggota masyarakat ekonomi ASEAN untuk saling mencapai kesejahteraan dengan tanpa meningggalkan ketahanan dan kedaulatan masing-masing Negara tentunya mengiringi berlakunya MEA. Masing-masing Negara akan memanfaatkan semua peluang dalam pergaulan MEA untuk kemajuan dan keuntungan negaranya. Kompetisi tersebut tentunya juga kaan menimbulkan persaingan dalam mempertahanan ketahanan dan kedaulatan Negara masing-masing.

Adanya aliran barang, jasa, investasi dan manusia sebagai tenaga kerja tentunya akan diikuti pula aliran budaya yang akan saling mempengaruhi. Kondisi tersebut akan menimbukan peluang siapa yang lemah akan terdesak oleh yang lebih kuat. Apakah bangsa Indonesia memiliki ketahanan nasional dan pengaruh yang lebih kuat diantara bangsa ASEAN lain? Perlu kesiapan dan pendidikan bagi setiap generasi muda kita untuk memupuk kekuatan dan ketahanan nasional kita.

Disisi lain, kondisi negara kita yang saat ini semakin mengkhawatirkan yang disebabkan krisis moral dikalangan masyarakat, berdampak pada krisis ketahanan yang ada dalam negara ini. Karena suatu negara jika ingin tangguh haruslah bermula dari tangguhnya pribadi-pribadi masyarakat enduduknya. Terbentuknya pribadi-pribadi masyarakat yang kuat tersebut tentunya berasal dari adanya keluarga yang kuat pula karena keluarga merupakan pendidikan dini dan perancang pendidikan selanjutnya bagi setiap anak-anak.

Melihat fenomena yang menimpa generasi muda calon penerus masa depan bangsa ini kita merasa prihatin. Banyak muncul dimedia massa sederet kasus kriminal seperti pejabat korupsi, maraknya kasus kekerasan di kalangan remaja, penyalahgunaan narkoba, hingga anak-anak SD yang gemar melihat video porno, bermula dan berawal dari moral para pelaku yang rusak dan bermasalah. ${ }^{1}$

Korupsi adalah salah satu bentuk krisis karakter yang dampaknya sangat buruk bagi bangsa Indonesia. ${ }^{2}$ Selain itu sikap mental yang memandang bahwa kemajuan bisa diperoleh secara mudah, tanpa kerja keras, bisa dicapai dengan menadahkan tangan dan dengan menuntut ke kiri dan ke kanan begitu pula

\footnotetext{
1 http:/ / www.republika.co.id/berita/jurnalisme-warga/wacana/11/06/20/ln385r-krisismoral-dan-keteladanan diunduh 20 April 2015.

2 Astuti, Siti Irene. 2010 "Pendekatan Holistik dan Kontekstual dalam mengatasi Krisis Karakter di Indonesia." Cakrawala Pendidikan 1.3.
}

RI'AYAH, Vol. 01, No. 01 Januari-Juni 2016 
dengan kebiasaan menimpakan kesalahan kepada orang lain merupakan salah satu karakter yang menghambat kemajuan. ${ }^{3}$

Hasil penelitian di 16 provinsi di tanah air, ditemukan 2,6 persen siswa SLTP sederajat pernah menggunakan narkoba, dan 4,7 persen siswa SMA terdata pernah memakai barang haram itu. Sementara untuk perguruan tinggi, ada 7,7 persen mahasiswa yang pernah mencoba narkoba. ${ }^{4}$

Kecenderungan pergaulan bebas yang mengarah pada perilaku sex pra nikah (berkencan, berpegangan tangan, mencium pipi, berpelukan, mencium bibir, memegang buah dada di atas baju, memegang buah dada di balik baju, memegang alat kelamin di atas baju, memegang alat kelamin di bawah celana, dan melakukan senggama) sudah menjadi sesuatu yang biasa, padahal hal tersebut tidak boleh terjadi. ${ }^{5}$

Sejak tahun 2012 hingga 2014 bulan Juli, kasus aborsi di Indonesia mencapai 2,5 juta orang dengan rician per tahun kasus aborsi 750 ribu per tahun atau 7 ribu dalam sehari dan 30 persen pelakunya adalah remaja SMP dan SMA. Fenomena tingginya remaja melakukan aborsi karena akibat perkosaan dan hubungan suka sama suka. ${ }^{6}$ Tentunya semua gambaran krisis ini semakin mengkhawatirkan kita semua.

Tidak sedikit pula keluhan-keluhan yang muncul di dunia pendidikan kita, krisis moral, dan belum lagi ditambah dengan masalah yang ada pada Sumber Daya Manusia kita. Fenomena yang sama sekali tidak bisa kita remehkan atau dipandang sebelah mata, karena nasib bangsa ini yang akan menjadi taruhannya. Bila generasi bangsa ini miskin akan keteladanan dan krisis moral, meskipun kecerdasannya patut dibanggakan, justru mereka inilah yang merugikan negara dan masyarakat, dan mereka pula yang akan membawa negara pada kehancuran.

Derasnya arus globalisasi informasi dan budaya semakin berpotensi menambah krisis moral remaja dan generasi muda kita. Terlebih media massa dan televisi saat ini relatif kurang memperhatikan kontrol terhadap informasi yang mereka berikan apakah nantinya akan berdampak positif bagi generasi muda ataukah sebaliknya. Informasi dan berita sepertinya meluncur begitu saja tanpa memperhatikan dampak bagi generasi muda.

Bila masyarakatnya telah tertata moralnya dengan baik, maka negarapun akan menjadi tangguh dan lebih dinamis. Berdasarkan kondisi tersebut, maka

3 Raka, Gede, 2007. "Pendidikan Membangun Karakter". Makalah, Orasi Perguruan Taman Siswa. Bandung 10 Februari 2007.

4 Tryas. 2014. 22 Persen Pengguna Narkoba Kalangan Pelajar. http://www.harianterbit.com/ read/2014/09/13/8219/18/18/22-Persen-Pengguna-NarkobaKalangan-Pelajar. diakses tanggal 17 April 2015.

5 Samino. 2012. "Analisis Perilaku Sex Remaja SMAN 14 Bandar Lampung 2011". Jurnal Dunia Kesmas Vol 1. Nor 4 : 175-183.

6 Ardiantofani, C. 2014. 30 Persen Kasus Aborsi di Jatim Pelakunya Remaja. http://surabayanews.co.id/2014/08/18/3745/30-persen-kasus-aborsi-di-jatim-pelakunyaremaja.html. Diakses tanggal 17 April 2015.

RI'AYAH, Vol. 01, No. 01 Januari-Juni 2016 
membahas tentang Ketahanan keluarga sebagai basis dalam pengokohan ketahanan nasional menjadi penting. Apalagi saat ini kita sudah memasuki pasar bebas ASEAN dalam format MEA. Diperlukan perbaikan secara kultural terhadap krisis moral dan karakter bangsa ini melalui penguatan fungsi keluarga.

Berdasarkan uraian diatas, perumusan masalah pada karya tulis ini adalah:

1. Apakah fungsi dan peran sebuah keluarga dalam membentuk SDM unggul untuk dapat bersaing dalam MEA?

2. Bagaimanakah pengaruh ketahanan keluarga terhadap ketahanan nasional ditengah persaingan regional dalam MEA?

Adapun tujuan penulisan ini adalah untuk menggambarkan pentingnya ketahanan keluarga dalam menopang ketahanan nasional dalam menghadapi persaingan regional dalam Masyarakat Ekonomi ASEAN (MEA).

\section{Sejarah Pembentukan MEA}

Awal pembentukan MEA bermula dari kesepakatan para pemimpin ASEAN dalam Konferensi Tingkat Tinggi (KTT) pada Desember 1997 di Kuala Lumpur, Malaysia. Kesepakatan tersebut bertujuan meningkatkan daya saing ASEAN serta bisa menyaingi Tiongkok dan India untuk menarik investasi asing. Modal asing dibutuhkan untuk meningkatkan lapangan pekerjaan dan kesejahteraan warga ASEAN. Saat itu, ASEAN meluncurkan inisiatif pembentukan integrasi kawasan ASEAN atau komunitas masyarakat ASEAN melalui ASEAN Vision 2020 ditengah berlangsungnya ASEAN Second Informal Summit. Inisiatif ini selanjutnya diwujudkan dalam bentuk roadmap jangka panjang yang bernama Hanoi Plan of Action yang disepakati pada 1998.

Dibentuknya MEA bertujuan untuk meningkatkan stabilitas perekonomian di kawasan ASEAN, serta diharapkan mampu mengatasi masalah-masalah di bidang ekonomi antar negara ASEAN. Selama hampir dua dekade, ASEAN terdiri dari lima Negara, yaitu Indonesia, Malaysia, Filipina, Singapura, dan Thailand yang pendiriannya dilakukan pada tahun 1967. Kemudian beberapa negara Asia Tenggara lainnya yang ikut bergabung dalam ASEAN antara lain Brunei Darussalam (tahun 1984), Vietnam (tahun 1995), Laos dan Myanmar (tahun 1997), dan Kamboja (tahun 1999).

\section{Peran Keluarga dalam Menumbuhkan Ketahanan Nasional Memasuki MEA}

Sebagai sistem sosial terkecil, keluarga memiliki pengaruh luar biasa dalam hal pembentukan karakter suatu individu. Bermula dari karakter individuindividu inilah akan berlanjut kepada terbentuknya karakter kumpulan individu dalam lingkup suami-isteri atau keluarga, dalam masyarakat dan akhirnya berdampak pada karakter sebuah bangsa.

Sebuah keluarga pada hakekatnya bukan hanya tempat berkumpulnya ayah, ibu dan anak tetapi lebih dari itu, keluarga hendaknya menjadi tempat

RI'AYAH, Vol. 01, No. 01 Januari-Juni 2016 
pendidikan karakter dan moral setiap anggota keluarga. Berhasil tidaknya seseorang menjalani kehidupan tergantung dari berhasil tidaknya keluarga itu menanamkan karakter dan moral yang benar pada anggota keluarganya untuk mengarungi kehidupan yang akan terus mereka jalani.

Kehidupan global dewasa ini, seperti hadirnya komunitas antar bangsa ASEAN dalam MEA akan berdampak positif dan negatif dalam kehidupan masyarakat Indonesia. Kondisi tersebut memunculkan tantangan globalisasi yang juga dapat diterjemahkan menjadi tuntutan untuk mengembangkan produktivitas, keunggulan kompetitif, dukungan infrastuktur baik umum, dukungan riset dan pengembangannya, serta keunggulan pelayanan dan administrasi.

Meskipun memiliki dampak positif berupa kemajuan teknologi, komunikasi, investasi, aliran bebas barang dan jasa, namun terdapat pula dampak negatif yang dirasakan, yaitu munculnya budaya permisif, gaya hidup yang keliru sehingga diperlukan sikap kehati-hatian dan kewaspadaan dalam membentuk sebuah rumahtangga yang dinamis. Inilah sebabnya masing masing individu perlu mengetahui pentingnya menjaga keluarga agar tidak mudah goyah dan rapuh.7

Sebuah keluarga yang kuat, kokoh dan tidak mudah rapuh, adalah sebuah keluarga yang masing masing anggotanya memiliki visi misi hidup yang jelas, bagi seorang Muslim visi misi hidupnya adalah beribadah kepada Allah SWT, Allah berfirman; "Aku tidak menciptakan jin dan manusia melainkan agar mereka berbadah kepada-Ku" (QS. Adz Dzariyat: 56). Beribadah yang dimaksud adalah meliputi, ketaatannya menjaga ibadah ibadah ritual maupun perilaku baiknya kepada sesama makhluk. Selain itu diperlukan pula komitmen yang kuat dari masing masing individu tersebut dalam menjaga nilai nilai positif dalam dirinya.

Sebuah keluarga hendaknya membentengi anggotanya dari style kehidupan yang hedonis dan permisif, karena hal itu akan menjadi sumber petaka bagi keluarga, dikarenakan mereka hanya berfikir tentang nikmat duniawi dan hawa nafsu. Keseimbangan kehidupan antara aspek spiritual dan material perlu ditekankan sehingga perlu dibingkai dengan nilai nilai kebaikan agar tidak menjadi kalap dengan gemerlap dunia.

Komunikasi yang harmonis dalam keluarga juga menjadi faktor penting dalam menjaga soliditas sebuah keluarga. Selain itu yang tidak kalah pentingnya adalah kesungguhan dalam mengontrol semua faktor faktor di atas agar keluarga memiliki antibodi yang kuat dalam menghadapi pengaruhpengaruh buruk dalam hidup.

Besarnya pengaruh pendidikan dan perhatian dalam keluarga terhadap moral dan karakter anak, sangat tampak dalam kehidupan sehari hari. Hasil penelitian SKRRI beberapa tahun lalu, di Indonesia menunjukkan bahwa remaja

7 Supriyatna, Usep. 2012. "Peranan Pendidikan di Keluarga Dalam Membina Akhlak Remaja." Prospektus Jurnal Ilmiah Unirow Tuban 1.1

RI'AYAH, Vol. 01, No. 01 Januari-Juni 2016 
perempuan dan laki laki berusia 15-24 yang mengatakan pernah melakukan hubungan seksual pranikah masing masing $1 \%$ pada wanita dan $6 \%$ pada pria. Perilaku seksual pranikah dikalangan remaja diperkuat data dari Depkes tahun 2009 di empat kota besar (Medan, Jakarta pusat, Bandung, Surabaya) menunjukkan bahwa 35,9\% remaja mempunyai teman yang sudah pernah melakukan hubungan seks pranikah dan 6,9\% responden telah melakukan hubungan seks pranikah. ${ }^{8}$ Belum lagi masalah tawuran pelajar, narkoba dan lain sebagainya.

Masalah kerusakan moral seseorang tentu akan mengganggu ketentraman oranglain, jika dalam suatu masyarakat banyak yang rusak moralnya, maka akan goncanglah keadaan masyarakat. Bila kita tinjau keadaan masyarakat di Indonesia terutama di kota besar sekarang ini, akan kita dapati bahwa moral sebagian anggota masyarakat telah rusak atau mulai merosot, dimana kita lihat kepentingan umum tidak lagi menjadi nomor satu, akan tetapi kepentingan dan keuntungan pribadi lah yang menonjol pada banyak orang. ${ }^{9}$

Menurut Mardiya ${ }^{10}$, wanita sebagai salah satu bagian dalam keluarga dan berposisi sebagai istri pendamping suami atau ibu bagi anak anak, memiliki peranan yang sangat besar dalam menciptakan ketahanan sebuah keluarga, yaitu: pertama, dalam pelaksanaan fungsi keagamaan, ibu adalah contoh panutan bagi anak anaknya. Ketekunan ibu dalam beribadah membawa pengaruh sangat besar bagi anak anaknya, termasuk sikap dan perilaku sehari hari yang sesuai dengan norma agama. ${ }^{11}$

Kedua, dalam pelaksanaan fungsi social budaya, ibu adalah contoh ideal perilaku social dan budaya yang akan ditiru oleh anak anaknya. Cara bertutur, bersikap, berpakaian, bertindak yang sesuai budaya timur menjadi sesuai yang wajib dimiliki oleh seorang ibu agar anak anaknya juga bisa melestarikan dan mengembangkan budaya bangsa dengan penuh rasa bangga.

Ketiga, dalam pelaksanaan fungsi cinta kasih, ibu adalah pelopor utama dalam keluarga yang memberikan kasih sayang yang ikhlas pada anak anak dan suami. Ibu selalu memberikan nasehat yang baik dalam hubungan anak dengan anak, anak dengan orangtua serta hubungan dengan tetangga dan kerabat.

Kempat, dalam pelaksanaan fungsi melindungi, ibu selalu berusaha menumbuhkan rasa aman dan kehangatan bagi seluruh anaknya.

Kelima, dalam pelaksanaan fungsi reproduksi, ibu menjadi penopang utama dalm pengaturan jarak kelahiran. Ibu juga selalu memberi nasehat pada

\footnotetext{
8 BPS. 2012. Badan Pusat Statistik. Survey Kesehatan Reproduksi Remaja. Jakarta

9 Komariah, K. S. 2011. Model Pendidikan Nilai Moral bagi Para Remaja Menurut Perspektif Islam. Jurnal Pendidikan Agama Islam -Ta'lim Vol. 9 No. 1 : 45-54.

10 http://www.kulonprogokab.go.id/v21/files/Optimalisasi Fungsi Keluarga.pdf, diunduh 24 April 2015.

11 Bakri, Syamsul. 2011. "Agama, Persoalan Sosial, dan Krisis Moral." Jurnal Komunika 3.1 : 37 45.
}

RI'AYAH, Vol. 01, No. 01 Januari-Juni 2016 
putra putrinya agar pandai dalam bergaul sehingga tidak terjadi kehamilan sebelum menikah.

Keenam, dalam pelaksanaan fungsi sosialisasi dan pendidikan, ibu menjadi kunci utama dalam mendidik dan mengasuh anak anaknya. Ibu pula yang mengajari anaknya agar memiliki juwa social tinggi, supel dalam pergaulan dan pandai menempatkan diri dalam lingkungan sosial.

Ketujuh, dalam pelaksanaan fungsi ekonomi, ibu terkadang menjadi penyangga kedua ekonomi keluarga.

Kedelapan, dalam pelaksanaan fungsi pembinaan lingkungan. Ibu selalu mengajarkan anak anak untuk mampu menciptakan lingkungan yang nyaman, menjaga kebersihan, memelihara tanaman, serta memanfaatkan kebun dan pekarangan untuk tanaman sayuran dan obat yang bermanfaat.

Dalam uraian tersebut, jelaslah bahwa wanita yang dalam hal ini adalah ibu dalam sebuah keluarga memiliki peran yang amat penting dalam menciptakan ketahanan keluarga. Tanpa dukungan wanita, kaum lelaki yang dalam hal ini adalah suami, tidak memiliki kekuatan yang memadai untuk menciptakan keluarga yang sejahtera. Apalagi seorang ayah akan selalu banyak pergi dari rumah, karena harus mencari nafkah. Praktis semua pekerjaan rumah dan merawat anak menjadi tugas dan tanggung jawab seorang ibu. Sehingga ibu pula yang mencetak cerah buramnya masa depan keluarga dalam arti yang sebenarnya.

Tindak kekerasan orangtua terhadap anak makin menjadi perbincangan hangat ditengah masyarakat, sebab anak memiliki hak atas perlindungan perkembangan fisik dan mentalnya, terlebih lagi mereka adalah generasi penerus kita semua. Seorang anak tergantung dari bagaimana dia mendapat didikan dari lingkungannya, karena itu mereka diharapkan nantinya dapat menjadi manusia dewasa yang penuh cinta pada sesame jika pertumbuhan anak diiringi dengan perhatian dan cinta dari lingkungannya.

Masalah komunikasi antara orangtua dan anak adalah hal penting, karena itu orangtua perlu menaruh perhatian pada hal hal yang menyangkut komunikasi dengan anak, dalam beberapa hal, antara lain: bermain bersama, melakukan kerjasama, dialog, memberikan kebebasan memilih, tentunya sambil diberikan arahan yang benar, menghargai pendapat anak, saling membantu antara orangtua dan anak. Sehingga dengan adanya pola komunikasi yang baik diharapkan hubungan orangtua dan anak akan menjadi baik pula.

Pada dasarnya orangtua di rumah tetaplah berposisi sebagai pemimpin bagi anak anaknya, karena itu orangtua mesti memiliki kreativitas dalam gaya kepemimpinannya agar permasalahan permasalahan dalam hal komunikasi dengan anak dapat diatasi dengan baik, misalkan saja dalam hal komunikasi tentang bahaya narkoba, banyak orang berfikir bahwa terlalu dini membicarakan masalah narkoba pada anak, padahal sikap dan kebiasaan yang terbentuk pada 
usia dini akan berpengaruh terhadap keputusan keputusan yang diambil saat mereka tumbuh dan berkembang dimasa berikutnya.

Contoh pada usia sekolah dasar (6 sampai 12 tahun) anak sedang mengalami proses interaksi yang lebih mandiri dengan lingkungannya, dalam artian pada usia ini anak sudah tidak terlalu sepenuhnya dalam perawatan atau pemantauan khusus dari orangtua atau pengasuhnya lagi, selain itu anak yang tergolong dalam kelompok ini biasanya menunjukkan minat yang makin bertambah luas mengenai dunia di luar rumah dan keluarganya, anak juga mulai dapat memahami diskusi yang lebih rumit, mereka juga merasa tertarik mengetahui bagaimana narkoba dapat mempengaruhi otak dan tubuh penggunanya.

Berikut ini beberapa hal yang dapat dilakukan orangtua dalam pendidikan narkoba pada anak, dalam kelompok usia tersebut:

- Jelaskan pada anak arti dari ketagihan dalam Bahasa yang sederhana, misalkan dengan mengatakan penggunaan obat yang telah menjadi kebiasaan buruk akan sulit dihentikan, pujilah jika anak adapat merawat dirinya

- Alasan alas an mengapa penggunaan narkoba dapat membahayakan seseorang yang sedang dalam masa pertumbuhan

- Masalah masalah yang dapat ditimbulkan penggunaan narkoba, tidak hanya terbatas pada pemakai saja tapi juga mempengaruhi keluarga dan lingkungan sekitarnya.

Dengan adanya komunikasi yang baik antara orangtua dan anak, maka setidaknya permasalahan permasalahan dapat diminimalisir, karena bagaimanapun keluarga yang sehat dan tangguh akan sangat mempengaruhi kondisi masyarakat sekitarnya.

Seperti yang kita ketahui bersama bahwa masalah moral sangat penting dalam kehidupan kita, karena pentinya moral itu ada yang mengungkapkan bahwa ukuran baik buruknya suatu bangsa tergantung pada moral bangsa tersebut. Apabila bangsa tersebut moralnya hancur maka akan hancurlah bangsa tersebut bersama moralnya itu. Moral memang sangat penting bagi masyarakat dan bangsa, kalau moral rusak, ketentraman dan kehormatan bangsa itu akan hilang. Oleh karena itu untuk memelihara kelangsungan hidup sebuah bangsa yang terhormat maka perlu sekali memperhatikan pendidikan moral, baik dalam keluarga, sekolah maupun masyarakat. ${ }^{12}$

Bagi seorang Muslim, masalah akhlaq dan moral adalah hal yang serius untuk diperhatikan bahkan ada landasan syar'i yang mengatakan: "Wahai orang orang yang beriman, peliharalah dirimu dan keluargamu dari api neraka yang bahan bakarnya adalah manusia dan batu, penjaganya malaikat malaikat yang kasar dank keras,

12 Komariah, K. S. 2011. Model Pendidikan Nilai Moral bagi Para Remaja Menurut Perspektif Islam. Jurnal Pendidikan Agama Islam -Ta'lim Vol. 9 No. 1 : 45-54.

RI'AYAH, Vol. 01, No. 01 Januari-Juni 2016 
yang tidak durhaka kepada Allah terhadap apa yang Dia perintahkan kepada mereka yang selalu mengerjakan apa yang diperintahkan" (QS. At Tahrim: 6).

Karena itu setiap individu muslim perlu mengetahui dasar dasar ketahanan keluarga agar keluarganya tidak mudah goyah dan rapuh, dan dasar itu adalah visi dan misi hidup yang benar dari seluruh anggota keluarga, komitmen keislaman yang kokoh, persepsi yang utuh tentang keluarga dari masing masing anggota dan membangun keterpaduan dan kemitraan dalam keluarga.

Namun upaya membangun ketahanan dalam keluarga tidak selalu berjalan dengan mulus, karena selalu ada tantangan tantangan dari dalam maupun dari luar keluarga itu sendiri. Dari sisi internal keluarga misalnya adanya tantangan lemahnya komitmen keislaman, serta lemahnya komunikasi antar anggota keluarga, dan tantangan eksternal adalah dasyatnya arus hidup jahiliyah. Karena itu, fungsi keluarga harus diperkuat yaitu fungsi psikologisnya, sosiologisnya, fisiologisnya dan fungsi pendidikan dan dakwahnya. Adapun dasar dasar ketahanan keluarga meliputi visi dan misi hidup yang benar.

Masalah kekokohan dan ketahanan dalam keluarga akan berpengaruh besar terhadap kekokohan dan ketahanan sebuah masyarakat di suatu Negara. Bila keluarga keluarga dalam suatu lingkungan masyarakatnya dinamis, maka negarapun akan merasakan dampak positifnya. Sebagaimana pendapat ahli yang mengatakan bahwa, ketahanan nasional adalah kondisi dinamis bangsa yang meliputi segenap aspek kehidupan nasional yang terintegrasi. ${ }^{13}$

Menurut Harjomataram, ketahanan nasional adalah keuletan dan daya tahan suatu bangsa untuk mengembangkan kekuatan nasional dalam menghadapi segala tantangan dan ancaman dari dalam atau luar, langsung atau tidak langsung dan bisa membahayakan kehidupan nasional. ${ }^{14}$

Karena itu, jelaslah bahwa daya tahan suatu bangsa dalam menghadapi segala tantangan sangat tergantung dari daya tahan dan kekuatan sebuah masyarakat yang terdiri dari keluarga keluarga itu sendiri. Sehingga baiknya sebuah keluarga akan berpengaruh terhadap keadaan suatu masyarakat, dan dinamisnya sebuah masyarakat akan sangat mempengaruhi ketahanan suatu Negara itu sendiri. Penanaman moral dan budi pekerti sejak usia dini dapat memperbaiki kondisi generasi penerus bangsa saat ini ${ }^{15}$

Melalui pendidikan formal dan keluarga, dapat ditumbuhkan sikap dan budaya konsumen masyarakat Indonesia yang mencintai dan mempercayai

13 Soedarsono, Soemarno. 1997. Ketahanan pribadi \& ketahanan keluarga sebagai tumpuan ketahanan nasional. Intermasa.

${ }^{14}$ Ketahanan nasional. Kerja sama penerbitan Balai Pustaka [dan] Lemhannas, 1995.

15 Untari, Mei Fita Asri, Teguh Supriyabto, and Hari Bhakti Mardikantoro. 2012 "Pengembangan Cerita Anak Berwawasan Budi Pekerti Bagi Pendidikan Karakter." Journal of Primary Education 1.1

RI'AYAH, Vol. 01, No. 01 Januari-Juni 2016 
produksi dalam negeri. Hal ini akan menciptakan ketahanan ekonomi nasional, mendukung produktivitas dan kreativitas nasional.

Dalam ketahanan nasional Indonesia tidak mengutamakan sikap konfrontatif, tidak mengandalkan kekuasaan dan kekuatan fisik semata tapi lebih mengutamakan sikap konsultatif, kerjasama serta saling menghargai dengan mengandalkan kekuatan moral dan kepribadian masyarakat. Kesatuan dan kenyamanan hidup bersama ditengah-tengah masyarakat adalah modal penting dalam mewujudkan ketahanan nasional Negara kita ditengah komunitas Masyarakat Ekonomi ASEAN.

\section{Penutup}

Setiap keluarga memiliki peran yang signifikan dalam pembentukan karakter dan moral anak. Pendidikan dan perhatian orangtua terhadap masa depan anak sangat berpengaruh pada karakter dan moral anak. Memalui karakter dan moral anak yang baik dan tangguh maka sebuah keluarga akan menjadi kuat, daya imunitas terhadap pengaruh negatif dalam kehidupan juga dapat menjadikan generasi muda menjadi lebih dinamis. Keluarga yang kuat akan melahirkan pribadi-pribadi yang unggul, terbentuk keluarga dan masyarakat yang unggul sehingga terwujud ketahanan nasional. Keluarga yang tangguh akan memperkokoh ketahanan nasional dalam memasuki pergaulan regional Masyarakat Ekonomi ASEAN.

\section{Saran}

Hendaknya setiap keluarga berusaha menjadi sarana terbaik dalam pendidikan mental dan karakter anggota keluarga terutama anak untuk menjadikan pribadi yang baik dan tangguh. Setisp pribadi anak bangsa yang berkualitas maka pada akhirnya kondisi masyarakatpun akan baik dan berkualitas, ketahanan negara akan semakin kuat dan kokoh dalam memasuki persaingan antar bangsa-bangsa ASEAN dalam format MEA.

\section{Daftar Pustaka}

Ardiantofani, C. 2014. 30 Persen Kasus Aborsi di Jatim Pelakunya Remaja. http:/ / surabayanews.co.id/2014/08/18/3745/30-persen-kasus-aborsi-dijatim-pelakunya-remaja.html. Diakses tanggal17 April 2015.

Astuti, Siti Irene. 2010 "Pendekatan Holistik dan Kontekstual dalam mengatasi Krisis Karakter di Indonesia". Cakrawala Pendidikan 1.3.

Bakri, Syamsul. 2011. "Agama, Persoalan Sosial, dan Krisis Moral." Jurnal Komunika $3.1: 37-45$.

Badan Pusat Statistik. 2012. Survey Kesehatan Reproduksi Remaja. Jakarta: Ketahanan nasional. Kerja sama penerbitan Balai Pustaka [dan] Lemhannas, 1995.

Komariah, K. S. 2011. “Model Pendidikan Nilai Moral bagi Para Remaja Menurut Perspektif Islam”. Jurnal Pendidikan Agama Islam -Ta'lim Vol. 9 No. 1 : 45-54.

RI'AYAH, Vol. 01, No. 01 Januari-Juni 2016 
Raka, Gede, 2007. "Pendidikan Membangun Karakter". (Makalah, Orasi Perguruan Taman Siswa). Bandung 10 Februari 2007.

Samino. 2012. "Analisis Perilaku Sex Remaja Sman 14 Bandar Lampung 2011". Jurnal Dunia Kesmas Vol 1. Nor 4 : 175-183.

Soedarsono, Soemarno. 1997. Ketahanan Pribadi \& Ketahanan Keluarga Sebagai Tumpuan Ketahanan Nasional. Intermasa.

Supriyatna, Usep. 2012. "Peranan Pendidikan di Keluarga Dalam Membina Akhlak Remaja". Prospektus Jurnal Ilmiah Unirow Tuban 1.1

Tryas. 2014. 22 Persen Pengguna Narkoba Kalangan Pelajar. http://www.harian terbit.com/read/2014/09/13/8219/18/18/22-Persen-PenggunaNarkoba-Kalangan-Pelajar. diakses tanggal 17 April 2015.

Untari, Mei Fita Asri, Teguh Supriyabto, and Hari Bhakti Mardikantoro. 2012 "Pengembangan Cerita Anak Berwawasan Budi Pekerti Bagi Pendidikan Karakter." Journal of Primary Education 1.1.

http://www.kulonprogokab.go.id/v21/files/Optimalisasi_Fungsi_Keluarga.pdf , diunduh 24 April 2015.

http://www.republika.co.id/berita/jurnalismewarga/wacana/11/06/20/ln385r-krisis-moral-dan-keteladanan diunduh 20 Arpil 2015.

RI'AYAH, Vol. 01, No. 01 Januari-Juni 2016 